\title{
PREFACE OF THE NEW EDITOR-IN-CHIEF
}

Criminal Law Forum is a renowned journal, well known in the Anglo-American world and also, albeit less so, in continental Europe. Thus, it is a great honour for me to have been asked by the former editor-in-chief, William Schabas, and one of the founding editors, Roger Clark, to take over the editorship of the journal with this issue.

There is, of course, always room for improvement. The Journal, especially in recent years, has had a strong focus on international criminal law and justice. This is an increasingly important field with a universal reach, but there are also other important areas which should be covered by an international criminal law journal. First, the journal could become a forum for solid and innovative research in comparative criminal law and justice. Such research is strongly needed; existing research in English language is often limited to Englishspeaking (Anglo-American) jurisdictions, research on other jurisdictions predominantly being in non-English languages. Comparative criminal justice, in contrast to comparative criminal law, is a younger field with its special research needs. Even more strongly than comparative criminal law, it relies on interdisciplinary methods, stemming from criminal law, sociology and criminology, but also from political and police science. David Nelken's innovative book "Comparative Criminal Justice" (2010) is an excellent introduction into this area of research. Finally, European criminology, differently from its American counterpart, is often oriented toward integrating the normative perspective of criminal law and human rights into its approach, blurring somewhat the lines between comparative criminal law, comparative criminal justice and comparative criminology. In any case, relevant publications from comparative criminology are also welcome.

Secondly, the journal should take a strong(er) interest in European Criminal Law (ECL). This is a highly complex and nuanced area of law, stretching, as ECL in the broad sense (referring to the Council of

\footnotetext{
* Kai Ambos, Göttingen, Germany, 31 January 2016. E-mail: kambos@gwdg.de
} 
Europe), from Norway to Turkey and from Greenland to Russia, and, as ECL in the narrow sense (stricto sensu, some would argue), covering the European Union. To be sure, more importantly than the geographical application of ECL, is its highly developed and innovative character, reaching a level of harmonisation and approximation of the criminal law of the EU member States, which is clearly unique for a regional organisation. Given this fact, ECL is clearly of interest beyond the European borders, as a blueprint for other regions interested in achieving more harmony between their national criminal laws, or just as a field, which gives food for thought how to improve national, regional or international criminal law.

These are but a few ideas in which direction to steer the Forum in the coming years. The new focus is reflected in the new editorial structure, consisting of the editor-in-chief and his two associate editors (Stefanie Bock and Stefan Harrendorf), a new book review editor (Alexander Heinze) as well as a (newly composed) editorial board with regional and thematic editors, and, last but not least, an advisory board. All members of our boards, the Society for the Reform of Criminal Law, but also other colleagues and our readers, are cordially invited to help to improve the Forum in the next years and to widen its readership and geographical reach. This is not just a project of the executive editorial team but a collective enterprise. Ideas and suggestions are most welcome. The Forum wants to be inclusive, not a closed shop. The editorial process will be organized around the highly efficient Editorial Manager (http://www.editorialmanager.com/cril/ default.aspx) - a fully web-enabled submission and review system. All authors are kindly asked to submit their papers via this tool, which gives them the opportunity to keep track of the status of their sub mission. Thereby transparency, expediency and quality - via strict peer review - are guaranteed. 